\title{
Impacts of climate variability on the tuna economy of Seychelles
}

\author{
Jan Robinson ${ }^{1, *}$, Patrice Guillotreau ${ }^{2,3}$, Ramón Jiménez-Toribio ${ }^{4}$, Frédéric Lantz ${ }^{5}$, \\ ${\text { Lesya } \text { Nadzon }^{3,5} \text {, Juliette Dorizo }}^{1}$, Calvin Gerry ${ }^{1}$, Francis Marsac ${ }^{2}$ \\ ${ }^{1}$ Seychelles Fishing Authority, PO Box 449, Fishing Port, Mahé, Seychelles \\ ${ }^{2}$ IRD, BP 171, Avenue Jean Monnet, 34203 Sète Cedex, France \\ ${ }^{3}$ LEMNA, University of Nantes, IEMN, BP 52231, 44322 Nantes Cedex 3, France \\ ${ }^{4}$ MEMPES-AEA, University of Huelva, Plaza de la Merced, Huelva, Spain \\ ${ }^{5}$ IFP, $1 \&$ 4, avenue de Bois-Préau, 92852 Rueil-Malmaison Cedex, France
}

\begin{abstract}
Many small island states have developed economies that are strongly dependent on tuna fisheries. Consequently, they are vulnerable to the socio-economic effects of climate change and variability, processes that are known to impact tuna fisheries distribution and productivity. The aim of this study was to assess the impacts of climate oscillations on the tuna-dependent economy of Seychelles. Using a multiplier approach, the direct, indirect and induced economic effects of the tuna industry expenditure benefiting the Seychelles' economy declined in 1998 by 58, 26 and 35\%, respectively (mean decline: $42 \%$ ), a year of strong climate oscillation in the western Indian Ocean. Multivariate patterns in tuna purse-seine vessel expenditures in port were substantially modified by strong climate oscillations, particularly in 1998. A cointegration time-series model predicted that a $40 \%$ decline in tuna landings and transhipment in Port Victoria, a value commensurate with that observed in 1998, would result in a $34 \%$ loss for the local economy solely through reductions in cargo handling expenditures. Of several indices tested, the Indian Oscillation Index was best at predicting the probability of switching between low and high regimes of landings and transhipment, which translate into impacts for the economy. It is hypothesised that a late 2006/early 2007 climate oscillation was compounded by prior overfishing to produce a stronger impact on the fishery and economy of Seychelles. The effects of fishing and climate variability on tuna fisheries are complex and pose significant challenges for fisheries management and the economic development of countries in the Indian Ocean.
\end{abstract}

KEY WORDS: Climate variability $\cdot$ ENSO $\cdot$ Tuna fisheries $\cdot$ Seychelles economy - Resale or republication not permitted without written consent of the publisher

\section{INTRODUCTION}

Many countries, particularly small island developing states (SIDS), rely heavily on fisheries for economic development (Weber 1993, Zeller et al. 2006). For island states that are dependent on highly migratory and shared fish stocks, climate change poses significant challenges for effective governance and the maintenance of economic opportunities and benefits (Miller 2007). Developing countries are also vulnerable to climate change due to their poor adaptive capacity (Allison et al. 2009). However, the potential for adaptation will be enhanced through knowledge of the mechanisms linking physical and socio- ecological systems and the economic impacts of variability and change.

Climate variability operates on seasonal, inter-annual or decadal time scales and affects numerous biological and ecological processes (Stenseth et al. 2002), as well as fisheries (Lehodey et al. 1997, 2006). El Niño Southern Oscillation (ENSO) events impact ecosystem processes across the globe and are the major phenomena driving inter-annual ocean climate variability (Glantz 1996). ENSO is well detected in the Indian Ocean region by sea surface temperature (SST) and heat storage anomalies (Tourre \& White 1995, Nicholson 1997). Inter-annual climate variability in the Indian Ocean also results from coupled ocean-atmosphere-land interactions that oper- 
ate independently of the ENSO forcing that originates in the Pacific (Webster et al. 1999). The Indian Ocean zonal dipole mode (IOD; Saji et al. 1999, Webster et al. 1999) is a 'basin-scale pattern of surface and subsurface temperature that seriously affects the inter-annual climate anomalies of many nations around the Indian Ocean rim' (Meyers et al. 2007). The positive or negative IOD events may occur in the same years as ENSO, such as in 1998, or in its absence. ENSO and IOD processes have a profound effect on tuna fisheries in the region (Marsac 1991, 2008, Marsac \& Le Blanc 1998, Ménard et al. 2007). Of major concern to the tuna economy of Seychelles is the prediction that ENSO anomalies may increase in frequency and severity in relation to climate change (Timmermann et al. 1999, Yeh et al. 2009).
The 1997-1998 warm event, the result of one of the strongest ENSO events in the last century acting in phase with a positive IOD event, caused dramatic temperature and wind stress anomalies in the equatorial Indian Ocean (Murtugudde et al. 2000). At the same time, the distribution of the purse-seine tuna fishery underwent a substantial transformation, especially at the beginning of 1998 during the peak phase of El Niño (Marsac \& Le Blanc 1999). The usual fishing grounds of the western Indian Ocean (WIO) basin were deserted, and the fleets underwent a massive shift to the eastern basin, as far as $100^{\circ} \mathrm{E}$, a longitude never before reached by vessels based in the WIO (Marsac \& Le Blanc 1999; Fig. 1). Consequently, many vessels operated from Asian ports (notably Phuket, Thailand), and landings and ves-
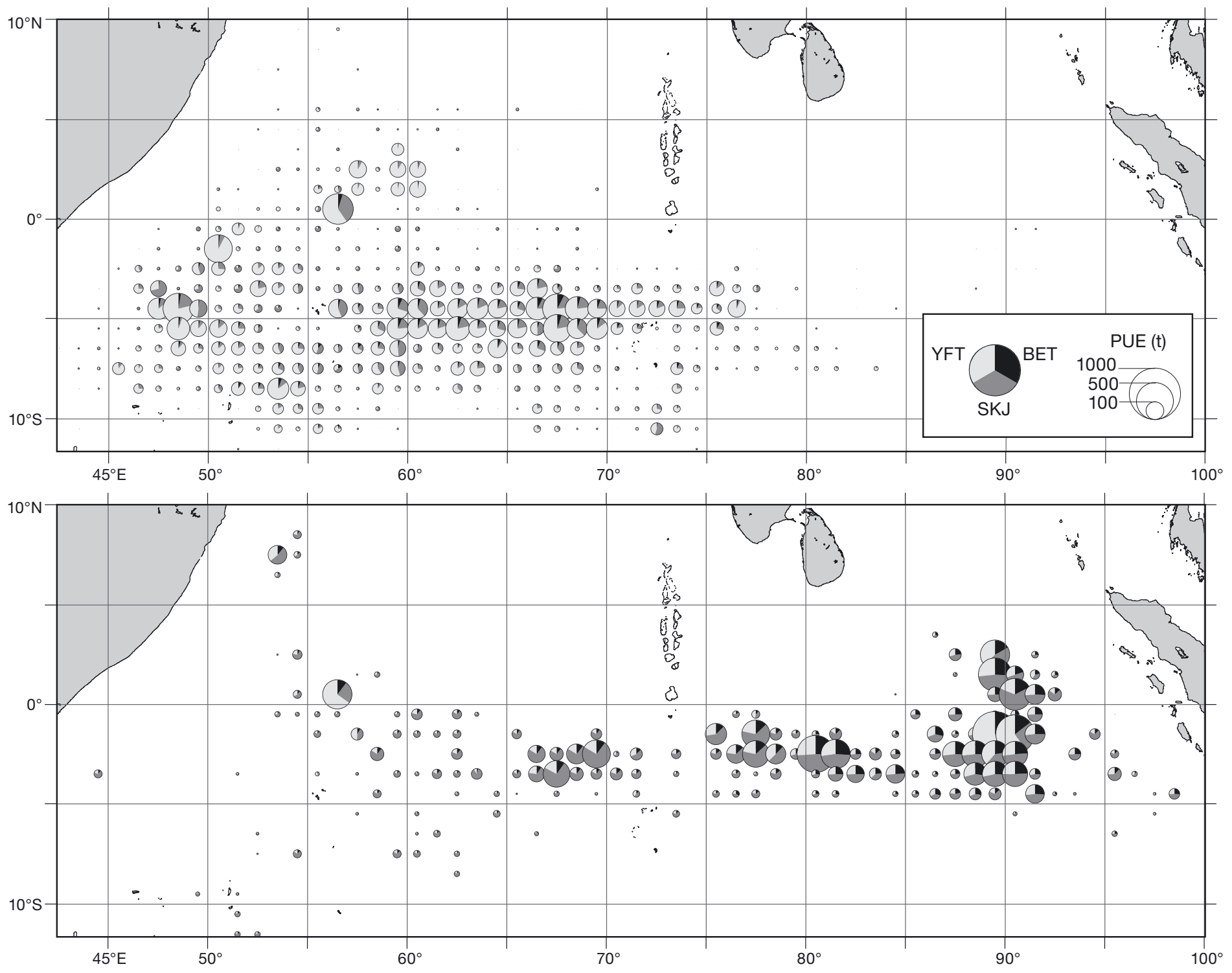

Fig. 1. Thunnus albacares, T. obesus and Katsuwonus pelamis. Average first quarter catch per unit effort (CPUE) of yellowfin tuna (YFT), bigeye tuna (BET) and skipjack tuna (SKJ) for the period 1992-2007 (upper panel) and 1998 only (lower panel) 
sel activity in Port Victoria, Seychelles, decreased substantially, resulting in negative economic impacts for the fishing industry (Payet 2005).

The eastward shift of the purse-seine tuna fleet during 1997-1998 was mediated through changes to habitat and behaviour of target tuna species affecting fishery catchability. The modifications caused by ENSO-related anomalies to the habitat of tropical tuna species in the WIO are summarised in Fig. 2a-c. In the core of the fishery $\left(0^{\circ}-10^{\circ} \mathrm{S} / 50^{\circ}-65^{\circ} \mathrm{E}\right)$ and during the fishing season on free schools (November to March), the strongest positive anomalies of the SST were recorded in late 1997-early 1998 and late 2006-early 2007 ( +5.1 and $+2.7^{\circ} \mathrm{C}$, respectively; Fig. 2a). These warm events were associated with an anomalous deep mixed layer $(+52$ and $+46 \mathrm{~m}$, respectively, for the 2 anomalous periods; Fig. 2 b) and below-normal primary productivity in the WIO (Fig. 2c). Tunas use the thermocline as an environmental cue (Yuen 1970, Evans et al. 1981, Cayré \& Marsac 1993, Marsac 1998) and distribute at greater depths in search of prey when the mixed layer deepens, becoming less vulnerable to surface gears like the purse seine. Conversely, primary productivity in the eastern Indian Ocean (EIO) is enhanced through upwelling during the dipole and ENSO-related events, creating a pattern opposite to that of the WIO (Fig. 2c). In the EIO, this habitat modification tends to retain tunas in the upper mixed layer and increase their vulnerability to the surface gears (Marsac \& Le Blanc 1999). The synchronicity between climate oscillations and catch per unit effort (CPUE) argues for a non-lagged effect of warm events on the catchability of tuna rather than for complex changes in the production regime (Ménard et al. 2007).

Centrally located relative to the most productive tuna fishing grounds of the Indian Ocean, Port Victoria consolidated its position as the major regional tuna hub early in the development of the purse-seine fishery. The fishery is dominated by European-owned fishing vessels and, under current fishing agreements, the European Union (EU) and ship owners paid 4.7 million Euros (€) and €6.5 million in 2005 and 2006, respectively, for access rights to the exclusive economic zone (EEZ) of Seychelles (source: Directorate-General for Martime Affairs and Fisheries-European, DG MARE, http://ec. europa.eu/fisheries/index_en.htm). Since 1992, annual catches by the purse-seine tuna fishery have varied between 250000 and 400000 tonnes (t), with a trend of increasing annual growth up to 2007 (Fig. 3). The percentage of tuna caught by the fishery and landed or transhipped in Port Victoria has grown to over $90 \%$ in 2006 and 2007. The development of the fishery peaked in 2006, when around 1.1 million $\mathrm{t}$ of tuna (54\% skipjack tuna Katsuwonus pelamis; $36 \%$ yellowfin tuna Thunnus albacares; and $10 \%$ bigeye tuna T. obesus) were caught in the Indian Ocean (source: Indian Ocean

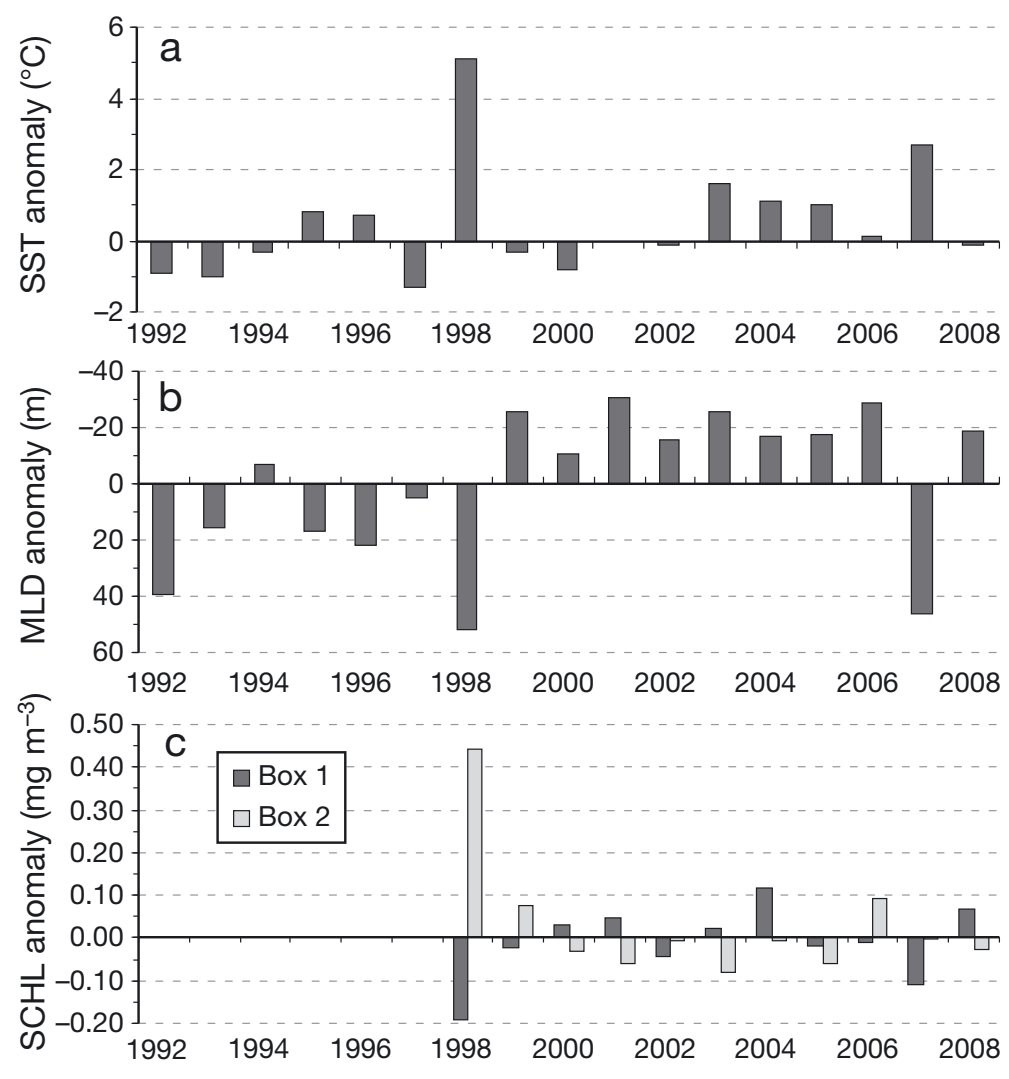

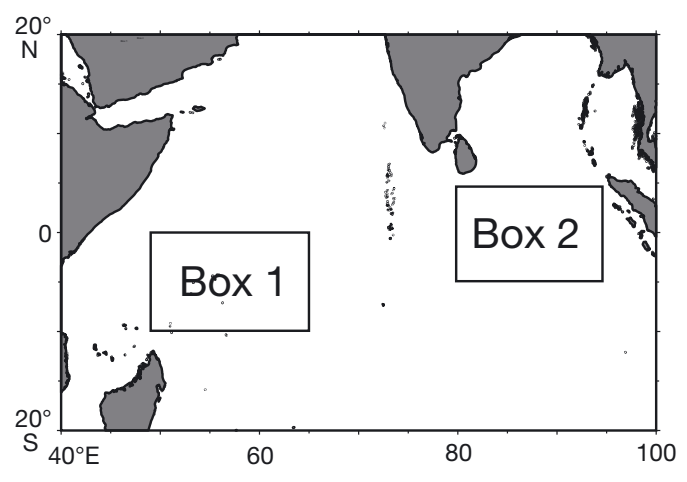

Fig. 2. Trends in (a) sea surface temperature (SST) anomalies, (b) mixed layer depth (MLD) anomalies and (c) surface chlorophyll concentration (SCHL) anomalies from 1992 to 2008 ([c] from 1998). The value for a given year $(y)$ is the average for November $(y-1)$ to March $(y)$. Dark gray bars: Box 1 in map $\left(50^{\circ}-65^{\circ} \mathrm{E} / 0^{\circ}-10^{\circ} \mathrm{S}\right)$, light gray bars: Box 2 in map $\left(80^{\circ}-95^{\circ} \mathrm{E} / 5^{\circ} \mathrm{N}-5^{\circ} \mathrm{S}\right)$. Data source: Global Assimilation Data Assimilation System (GODAS) of the NCEP, USA, www.cpc.noaa.gov/products/GODAS/. Anomalies are computed from climatology over the period 1980-2005 


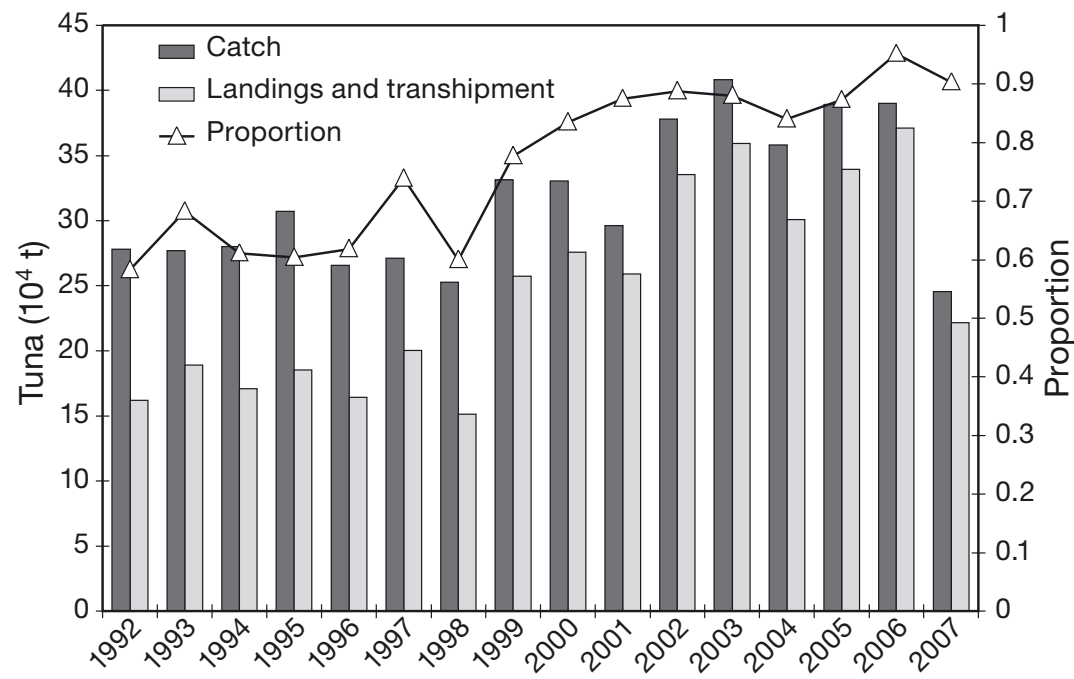

Fig. 3. Trends in annual Indian Ocean purse-seine vessel catches, annual landings and transhipment of frozen tuna to Port Victoria, and landings and transhipment as a proportion of catch

Tuna Commission, IOTC, www.iotc.org), constituting one-quarter of the global tuna catch.

The importance of tuna to the Seychelles economy has been enhanced through expansion in tuna canning capacity. Presently, the cannery (Indian Ocean Tuna Ltd, IOT) is one of the biggest in the world, with an average daily processing capacity of $350 \mathrm{t}$. Co-owned by foreign investors $(60 \%)$ and the Government of Seychelles $(40 \%)$, it is a major employer of the domestic economy, with 1975 workers in March 2007, of which 1149 were local workers $(58 \%)$ and 826 were expatriates $(42 \%)$. The company represents $19 \%$ of the formal employment in the private sector, and accounts for more than $90 \%$ of national exports (source: Central Bank of Seychelles, CBS, www.cbs.sc). Most canned tuna exports are destined for Europe, and Seychelles accounted for a $13 \%$ share of the European market in 2007. However, the position of Seychelles has been eroded by the rise of competing countries like Ecuador and Thailand, which rose above Seychelles in terms of European canned tuna market share after 2006. This erosion is due to the EU reduced-tariff quotas provided to SE Asian exporters between 2005 and 2008 and the relative competitiveness of these producers and Ecuador compared to small island states, as well as the availability of raw materials for processing.

The aim of this study was to assess the impacts of climate variability on the tuna-dependent economy of Seychelles. This assessment was achieved by crossing scientific knowledge on the linkages between climate and fisheries with economic models and several statistical methods (cluster analysis, cointegration, Markovswitching Vector Error Correction Model, VECM) to analyse the relationships between climate indices and available economic data relating to the purse-seine tuna fleet and fisheriesrelated industries.

\section{METHODS}

Data relating to the expenditure of purse-seine tuna vessels during calls to Port Victoria are collected by the Seychelles Fishing Authority (SFA) from the vessel agents acting for the Europeanowned fleets. These data consist mainly of port call expenses, including taxes, dues, agency and administrative fees, and expenses relating to labour, ship chandlery, utilities, transport, health, accommodation, repair and maintenance. In addition, data on the total expenses paid by the vessels for fuel are also collected (Appendix 1). Data were screened, verified and compiled by vessel type, quarter, year and expenditure categories. Purse-seine tuna fishery catch data were taken from the fisheries databases maintained by the SFA and imported to the economic database. Due to errors with some vessel trip data for records prior to 1992, data from 1992 to June 2008 were used in the study. In addition, we compiled economic data from other sources, namely expenditures of the tuna canning factory (IOT), bunker rates of the Seychelles Petroleum Company (SEYPEC), trade data and consumer price index from the National Statistics Bureau (NSB), and currency exchange rates from the CBS.

We employed the following climate indices in the analyses: (1) the Dipole Mode Index (DMI), the eastwest temperature gradient across the tropical Indian Ocean (Saji et al. 1999); (2) the Indian Oscillation Index (IOI), the difference in sea level pressure standardised anomalies between Seychelles and Darwin (Marsac \& Le Blanc 1998); (3) the Southern Oscillation Index (SOI), the difference in sea level pressure standardised anomalies between Tahiti and Darwin (Wright 1975), and (4) the Western Tropical Indian Ocean sea surface temperature index (WTIO), the surface temperatures in the region $50^{\circ}-70^{\circ} \mathrm{E}, 10^{\circ} \mathrm{S}-10^{\circ} \mathrm{N}$ (Reynolds et al. 2002).

\subsection{Estimating spillover effects using a multiplier approach}

The spillover effects of the expenditures by the purse-seine tuna fleet in Seychelles were estimated using an input-output model and a multiplier approach 
(Leontief 1970). A model of the spillover effects was constructed (Fig. 4). The expenditure of fishing vessels landing or transhipping in Port Victoria partly feeds into the national economy through the revenue transferred as wages or dividends (to shareholders) to Seychellois households that is not saved or spent on imported goods. In addition to the direct (fleet) and indirect (cannery, government) expenses, a looping effect induced by the household expenditure can be estimated (bottom left-hand side of Fig. 4). The standard multiplier impact is obtained by dividing the sum of direct, indirect and induced expenditure by total expenditure of the purse-seine tuna fleet. In the absence of information on the expenditure of households with members in tuna industry-related businesses, losses from the local economic circuit were estimated from information on the macroeconomic import rates and the savings rates. Between 2003 and 2006, the average proportion of gross national savings over the gross national disposable income was $5 \%$, while the macroeconomic rate of imports was $44 \%$ (source: National Bureau of Statistics, NSB, www.nsb.gov.sc/).
Each iteration of the induced expenditure was then reduced by the product of the domestically consumed part of the revenue (R) to calculate the multiplier (i.e. $0.95 \times[1-0.44] \times R=0.532 \times R)$. For direct and indirect effects, all expenditure series were deflated by the consumer price index (CPI base $100=$ year 2001) and averaged on a yearly basis over the period 1992-2008.

\subsection{Identifying climate effects on vessel expenditures}

To determine the relative importance of seasonal versus inter-annual trends, vessel expenditure data were analysed using principal component analyses (PCA) based on quarterly observations between 1992 and 2007. Seventeen variables of port call expenses by the purse-seine tuna fleet were selected as active continuous variables in the reduction process of the correlation matrix. Several other continuous variables (catch, effort, CPUE) were selected as illustrative variables in the process, i.e. simply projected on the facto-

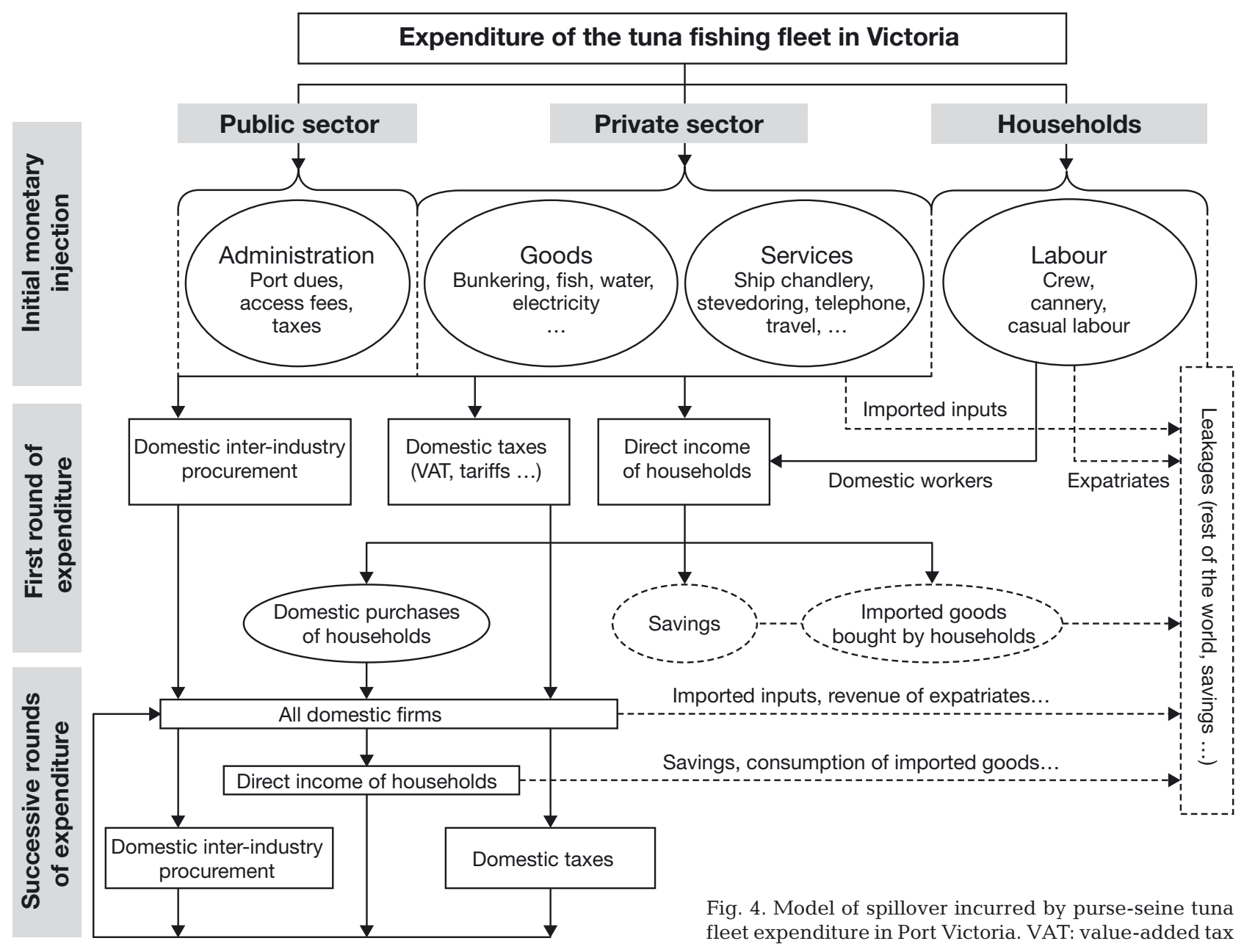


rial axes with no influence on the matrix reduction calculus. Six discrete variables (year, quarter and the 4 climate indices: IOI, SOI, DMI and WTIO) were also used as illustrative variables and projected on the principal components. A hierarchical ascending classification was then applied on the basis of the Ward criterion (minimum inertia within the clusters and maximum inertia between the clusters), where a break in the loss of total inertia (where total inertia is the sum of eigenvalues for all principal components) between 2 steps of the clustering process indicated the number of clusters to be chosen. Finally, each cluster was described by the most discriminating variables selected by a statistic, with its associated probability calculated from a normal law test of means between the cluster and the sample.

\subsection{Assessment of climate effects using cointegration and Markov analyses}

\subsubsection{Cointegration analysis}

To determine the economic effects of changes in landings and transhipment, it was necessary to assess whether a cause-effect relationship existed. While numerous expenses incurred by the vessels in Port Victoria are expected to be largely independent of landings and transhipment, cargo handling costs $(\mathrm{CHC})$ should be strongly related. The relationship between $\mathrm{CHC}$ and landings and transhipment was therefore tested through cointegration analysis (Johansen 1988), comprising unit root tests, cointegration tests, proportionality tests and the formulation of VECMs in order to study causality between the variables.

The first step of cointegration is to determine the stationarity between the variables. Using the Augmented Dickey-Fuller root test (Dickey \& Fuller 1981) and a stationarity test (KPSS; Kwiatkowski et al. 1992), the variables were found to be integrated of order 1, I(1), meaning the time-series had a unit root. The presence of non-stationary variables in models produces a series of problems in their estimates and in the tests that can be undertaken; when variables are integrated I(1) and present similar behaviour over time, as determined by regression analysis, for example, a spurious or casual relationship can easily be mistaken for a cause-effect relationship.

We selected Johansen's procedure (Johansen 1988), as it permits the performance of tests on the cointegration relationship(s) of the model. The basis of the procedure is an error correction model. Assuming that $\boldsymbol{x}_{t}$ is a vector which contains $k$ variables, in order to study whether there is 1 or several cointegration relationships, the model could be written as follows:

$$
\Delta \boldsymbol{x}_{t}=\boldsymbol{\mu}+\boldsymbol{\Phi} \boldsymbol{D}_{t}+\sum_{i=1}^{\mathrm{n}-1} \boldsymbol{\Gamma}_{i} \Delta \mathbf{x}_{t-i}+\boldsymbol{\Pi} \boldsymbol{x}_{t-n}+\varepsilon_{t}, \quad t=1,2, \ldots, T
$$

where $\Gamma_{i}=-\mathbf{I}+\Pi_{1}+\ldots+\Pi_{i}$ for $i=1, \ldots, \mathrm{n}-1, \Pi=-\mathbf{I}+$ $\Pi_{1}+\ldots+\Pi_{n}, \mathbf{I}$ is a $(k \times k)$ identity matrix, $\boldsymbol{D}_{t}$ is a vector of dummy variables (seasonal, etc.), $\boldsymbol{\Phi}$ is a matrix of the parameters which accompany the dummy variables, $\mu$ is a vector of intercepts, $\boldsymbol{\varepsilon}_{\boldsymbol{t}}$ is a $(k \times 1)$ vector of white noise error terms which are identically and independently distributed with mean 0 and covariance matrix $\boldsymbol{\Omega}, t$ represents time and, finally, $T$ is the number of observations used to estimate the model.

Hence, $\Pi$ contains the possible long-run equilibrium relationship(s) of Eq. (1). The number of cointegration relationships is provided by the rank of the matrix $\Pi(\mathrm{r})$ and it is determined by 2 asymptotically equivalent tests: the maximum eigenvalue test and the trace test.

Johansen's procedure permits the performance of tests on the coefficients $\alpha$ and $\beta$, using likelihood ratio tests (Johansen \& Juselius 1990, 1992, 1994). For our bivariate case, there were 2 time series in the vector $\boldsymbol{x}_{t}$. If both variables are cointegrated, the rank of $\Pi=\alpha \beta^{\prime}$ is equal to 1 and $\alpha$ and $\beta$ are $(2 \times 1)$ vectors. $\beta$ contains the r cointegration relationships, and $\alpha$ includes the adjustment speed parameters of the dependent variables towards the longrun equilibrium, which is represented by $\beta^{\prime} x_{t-n}$. Specifically, if the restriction $\beta^{\prime}=(1,-1)^{\prime}$ is tested, a proportionality test between 2 variables is undertaken.

Finally, Granger's causality was analysed using a bivariate VECM following Tiffin \& Dawson (2000), based on the long-run causality defined by Hall \& Milne (1994). Basically, the causality tests consist of checking whether the adjustment speed parameters of the dependent variables towards the long-run equilibrium $(\alpha)$ are significantly different from 0 . Developing Eq. (1), the following VECM is obtained:

$$
\begin{aligned}
\Delta X_{1, t}= & \mu_{1}+\sum_{i=1}^{3} \varphi_{1 i} D_{1 i}+\delta_{1}\left(X_{1, t-1}-\gamma X_{2, t-1}\right)+ \\
& \sum_{i=1}^{n-1} \alpha_{1 i} \Delta X_{1, t-i}+\sum_{i=1}^{n-1} \alpha_{2 i} \Delta X_{2, t-i}+\varepsilon_{1 t} \\
\Delta X_{2, t}= & \mu_{2}+\sum_{i=1}^{3} \varphi_{2 i} D_{2 i}+\delta_{2}\left(X_{1, t-1}-\gamma X_{2, t-1}\right)+ \\
& \sum_{i=1}^{n-1} \beta_{1 i} \Delta X_{1, t-i}+\sum_{i=1}^{n-1} \beta_{2 i} \Delta X_{2, t-i}+\varepsilon_{2 t}
\end{aligned}
$$

where $X_{1, t}$ and $X_{2, t}$ are the two variables for which causality is to be determined and are contained in the vector $\boldsymbol{x}_{t}$ in Eq. (1), $\Delta$ is the first difference operator and then $\Delta X_{1, t}=X_{1, t}-X_{1, t-1}$ and $\Delta X_{2, t}=X_{2, t}-X_{2, t-1}, \mu_{1}$ and $\mu_{2}$ are intercepts and are contained in the vector of intercepts $\mu$ in Eq. (1), $D_{1, i}$ and $D_{2, i}$ are seasonal dummy variables and are included in the vector of dummy variables $\boldsymbol{D}_{\boldsymbol{t}}$ in Eq. (1), $\varphi_{1 i}$ and and $\varphi_{2 i}$ represent the parameters which accompany the seasonal dummy variables in the first and second equation of the VECM, respectively, and are included in the matrix $\boldsymbol{\Phi}$ in Eq. (1) 
and, finally, $\delta_{1}$ and $\delta_{2}$ are the adjustment speed parameters in the first and second equation of the VECM, respectively, and are contained in $\boldsymbol{\alpha}$. $\varepsilon_{1, t}$ and $\varepsilon_{2, t}$ are white noise error terms which are contained in $\boldsymbol{\varepsilon}_{\boldsymbol{t}}$ in Eq. (1). $\alpha_{1, i}, \alpha_{2, i}, \beta_{1, i}$ and $\beta_{2, i}$ are parameters which are included in the matrix $\Gamma_{\mathbf{i}}$ in Eq. (1).

The null hypothesis that $X_{1, t}$ is Granger-caused by $X_{2, t}$ in the long run can be expressed using the following restrictions on the parameters of model (2): $\delta_{1}=0$. In contrast, the null hypothesis that $X_{2, t}$ is Grangercaused by $X_{1, t}$ in the long run can be expressed using the following restrictions on the parameters of model (2): $\delta_{2}=0$. A bidirectional causality relationship means that each variable has an influence on the other variable, while a unidirectional causality indicates that only 1 variable has causality of the other.

In our case, to specify Eq. (1), centred seasonal dummy variables were included to take into account the seasonal behaviour of the variables. An unrestricted constant had to be used in the model when the I(1) variables presented linear trends and an intercept different from 0 in the cointegration vectors. The Akaike Information Criterion (AIC; Lütkepohl 2005) determined the number of lags included, 4 being the maximum. Additionally, the model was checked for the absence of any statistical problems before determining the number of cointegration relationships, including autocorrelation (Lagrange Multiplier, LM) tests up to order 4 (Johansen 1995) and the Jarque-Bera Normality test, with the results showing that the model was correctly specified.

\subsubsection{Markov-switching Vector Error Correction Model (MS-VECM)}

Having confirmed causality between landings and transhipment and expenditure related to $\mathrm{CHC}$, and with the PCA identifying the existence of 2 seasonal and periodical regimes in the expenditure data, we then examined the effects of climate variability on the relationship between fishing effort and landings and transhipment. Following a standard typology of shipping costs (Stopford 1997), the purse-seine tuna vessel expenditures could be divided into $\mathrm{CHC}$ and the vessel or voyage costs, of which the bunker costs represented $86 \%$ on average. As a first step, the equilibrium between fishing effort and landings and transhipment was analysed through cointegration, with gasoil expenditure (bunker costs) used as a proxy of fishing effort. This analysis is based on the conventional production function equation $(\mathrm{H}=\mathrm{qEB}$ : where $\mathrm{H}=$ harvest, or catch; $\mathrm{q}=$ catchability; $\mathrm{E}=$ fishing effort, and $\mathrm{B}=$ biomass) and allowed for the influence of climate oscillations on landings and transhipment to be determined in an empirical model.
Secondly, we applied an MS-VECM method to model the probability of shifting between 2 regimes (high and low) of landings and transhipment in relation to climate oscillations. This time-series analysis was carried out in a vectorial autoregressive (VAR) context, allowing for regime change in terms of a Markov process. We adopted a multivariate MS-VECM that allows for regime switching mean equation parameters and variance-covariance matrix:

$$
\Delta x_{t}=\boldsymbol{\mu}\left(\mathbf{z}_{t}\right)+\sum_{j=1}^{k} \mathbf{A}_{j}\left(\mathbf{z}_{t}\right) \Delta x_{t-j}+\boldsymbol{\Pi}\left(\mathbf{z}_{t}\right) \Delta x_{t-1}+\mathbf{u}_{t}
$$

where $x_{t}=\left(s_{t}, f_{t}^{2}, \ldots, f_{t}^{k}\right) ; s t=$ landings (in log terms); $f_{t}^{i}=$ effort or input $i(i=2, \ldots, h)$ at time $t_{;} \boldsymbol{\mu}\left(\mathbf{z}_{t}\right)$ is a $k$-dimensional vector of regime-dependent intercept terms; $\boldsymbol{u}_{t} \sim$ $N I D\left(0, \Sigma\left(\mathbf{z}_{t}\right)\right)[N I D$ : normally and independently distributed] $\mathbf{A}_{j}$ is the Markov switching matrix (including the probabilities of switching from one regime to another); $\Pi\left(\mathbf{z}_{t}\right)=\alpha \beta^{\prime}$; the state $\mathbf{z}_{t} \in\{1, \ldots, M\}, M$ being the number of regimes.

The long-run relationship between variables was determined using the maximum likelihood procedure suggested by Johansen (1988). No regime switching was taken into account when obtaining estimates of the cointegrating vector. We analysed the dynamics of the above model using the error correction model algorithm that allows for 2 regimes of high and low volatility. We then proceeded with the Markov chain estimation, allowing for 2 regimes. Determination of the lag length was based on the Bayesian Information Criterion.

Finally, we assessed the impact of climate variability on the 2 regimes identified through MS-VECM by conducting regression analyses to determine how variation in 4 climate indices (described above) influenced the probability (pstar $\mathrm{p}^{*}$ ) of entering regime 1, i.e. a period of high levels of landings and transhipment. We introduced 3 seasonal dummy variables in the regression model for the first 3 annual quarters (D1, D2 and D3); a dummy variable was not introduced for the last quarter to avoid multi-collinearity with the intercept. Then, we tested the influence of each climate index with squared values of the indices used as explanatory variables in the regression analyses.

\section{RESULTS}

\subsection{Spillover effects estimated by a multiplier approach}

Using the average 2006 exchange rate $(€ 1=6.93$ Seychelles Rupees, SR) and excluding the cannery in a first step, the annual total (constant) expenditure of the tuna fleets valuing 240 million (M) $\mathrm{SR}_{2001}$ (i.e. €35M; average 1992-2006) gives an average induction effect of 
1.99 (Fig. 5). In terms of direct fleet expenditure (203 $\mathrm{MSR}_{2001}$, i.e. $€ 29 \mathrm{M}$ ), the spillover (indirect and induced expenditures) was estimated at $231 \mathrm{MSR}_{2001}$ (€33M). Thus, a net induced contribution represents more than twice the initial inflow for the rest of the economy. When IOT expenditures and their spillover effects were included in a second step, the coefficient of induction rose to 2.94. In other words, every 100 SR spent by the purse seine tuna fleet in Port Victoria leads to a final amount of nearly 300 SR for the Seychelles economy.

The evolution of direct, indirect and induced effects over the study period reveals an erosion of the coefficient of induction, concurrent with the elevation of total expenditure due to the steady fuel price increase since 2000 (Fig. 5). Interestingly, all types of effects show an inflexion point in 1998, the year of the main impacts of the 1997-1998 warm event in the WIO (with a mechanical increase of the induction coefficient due to lower expenses in that particular year). In 1998, the direct, indirect and induced effects declined by 58, 26 and $35 \%$ (42\% decrease overall), respectively, compared with a yearly growth trend of 19,3 and $5 \%(10 \%$ increase overall) for the same effects, respectively.

\subsection{Climate effects on purse-seine vessel expenditures}

The (deflated) expenditure data varied in their seasonal and time patterns with some showing a strong seasonal variation and little change over time (factor 1), while other variables exhibited a combination of change between years and seasons, lying between the axes (Fig. 6). Seasonal variation in expenditure is a response to seasonal variation in landings and transhipment, which are pronounced during the second quarter when the purse-seine tuna fleet mainly fishes in the Mozambique Channel and utilises other regional ports.

In projecting expenditure data as a factorial plan, 1998 is isolated from other years and clusters with the second quarter patterns of low expenditure and extreme values of 2 climatic indices, the IOI and the WTIO (Fig. 7). This suggests that anomalous ocean-climate conditions produce a similar response in expenditure to that typically observed during the second quarter of the year. Cluster analysis of seasonally adjusted quarterly expenditure data yielded an optimal number of 5 clusters and isolated 1994 and 1998 from the recurrent seasonal pattern, clustering most quarters from those years (55\% of observations in the cluster compared to an average of $13 \%$ ) and rejecting the null hypothesis of a random distribution. The level of tuna landings and transhipment in this cluster was $53 \%$ lower than average and can be considered as the seasonally adjusted impact of the 1997-1998 warm event on the Seychelles tuna economy.

\subsection{Climate effects identified using cointegration and Markov analyses}

\subsubsection{Cointegration analysis}

Prior to examining cointegration relationships, autocorrelation LM tests (4 lags; statistic: 3.10; $\mathrm{p}=0.54$ ) and

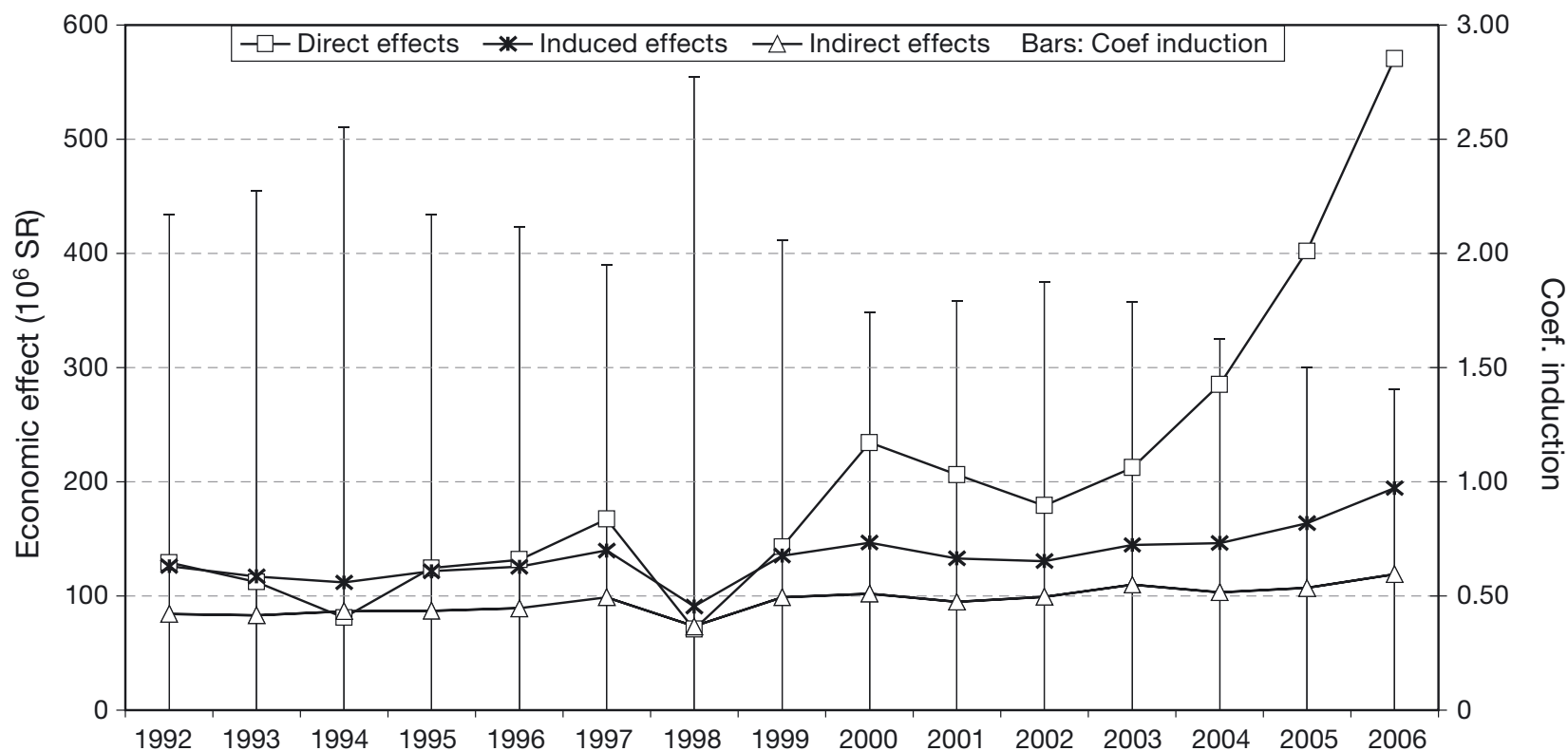

Fig. 5. Annual direct, indirect and induced effects (lines) of the tuna purse-seine fleet on the national economy (not including Indian Ocean Tuna Ltd) and annual values of the coefficient of induction (bars). Economic effects in units of million Seychelles Rupees (constant $\mathrm{SR}_{2001}$ ) 


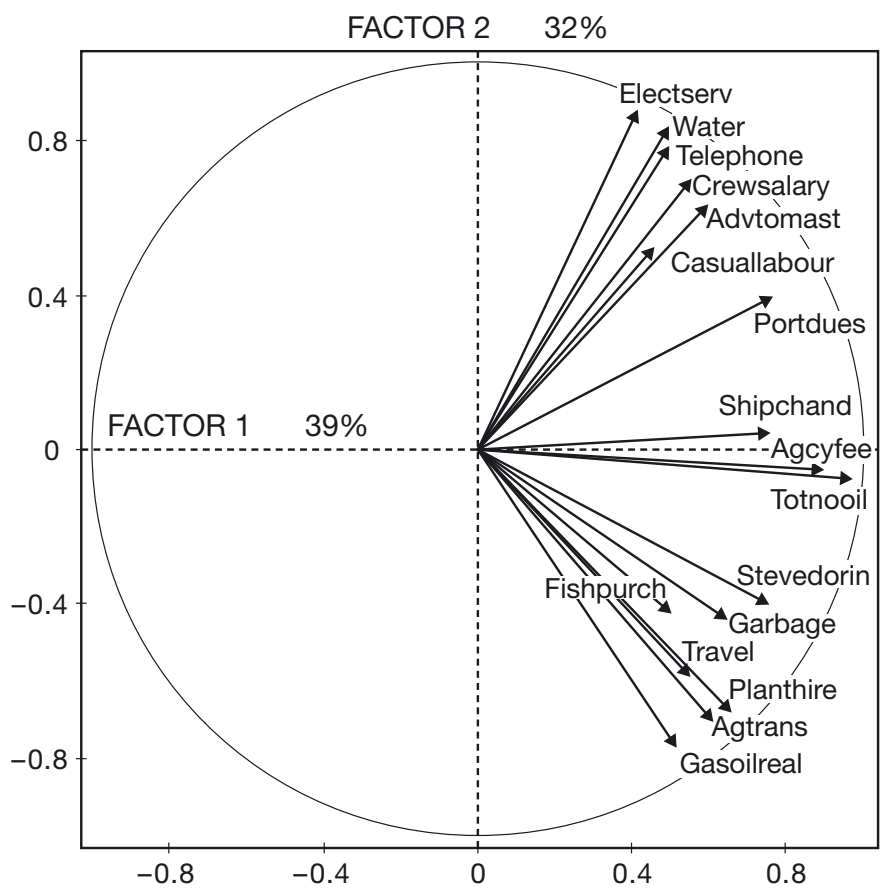

Fig. 6. Factorial map of the (deflated) purse-seine vessel expenditure variables. The inter-annual (time) trend is descending along factor 2 (vertical axis), the seasonal trend along factor 1 (horizontal axis). The first 2 eigenvalues accumulate $71 \%$ of the total variance. See Appendix for variable descriptions

the Jarque-Bera normality test (statistic: $7.35 ; \mathrm{p}=0.12$ ) determined that the model was specified correctly. The number of cointegration vectors was determined by cointegration rank tests using the critical values provided by Osterwald-Lenum (1992), achieved through a sequential testing procedure. First, the null hypothesis that there are 0 cointegration relationships was analysed; the statistics of the maximum eigenvalue and trace tests were 18.76 and 21.15 , respectively, and this hypothesis was rejected at the $1 \%$ significance level. Next, the null hypothesis that there is 1 cointegration relationship was investigated; the statistics of the maximum eigenvalue and trace tests were 2.35 , so this hypothesis could not be rejected. Therefore, both the trace test and the maximum eigenvalue test showed the existence of a cointegration relationship. All the characteristic roots were inside the unit circle; as 1 of the characteristic roots was almost $1(\mathrm{k}-\mathrm{r}$ =1), 1 cointegration vector was selected. Additionally, the proportionality test rejected the null hypothesis at the $1 \%$ significance level (test statistic $=11.21$ ).
Having shown cointegration between both variables, the cointegration relationship was estimated as follows:

$$
\mathrm{CHC}_{t}-1219592-116.12 \mathrm{LANDING}_{t}=\varepsilon_{t}
$$

There was bidirectional causality between $\mathrm{CHC}$ and landings and transhipment, i.e. each variable was influenced by the other in the model (causality of $\mathrm{CHC}$ on landings and transhipment: test statistic $=16.33, \mathrm{p}<0.01$; causality of landings and transhipment on $\mathrm{CHC}_{\text {; }}$ test statistic $=11.12, \mathrm{p}<0.01)$. Therefore, $\mathrm{CHC}$ increased by 116 SR when total landings and transhipment in Port Victoria increased by $1 \mathrm{t}$. This proportionality of $116 \mathrm{SR}$ $\mathrm{t}^{-1}$ of fish landed and transhipped corresponds well with the average unit price over the period. On average, with a standard level of $61632 \mathrm{t}$ landed and transhipped per quarter (mean 1992,1st quarter to 2008, 2nd quarter), the estimated CHC expenditure would be $8376092 \mathrm{SR}_{2001}$. Other things being equal, a $40 \%$ cut of landings and transhipment caused by a warming event as extreme as that of 1997-1998 would result in a total CHC expenditure of $5513492 \mathrm{SR}_{2001}$ per quarter, equating to a $34 \%$ loss for the local economy.

\subsubsection{Markovian analysis of the relationship between bunker costs and landings and transhipment}

The long-term equilibrium between bunker costs and landings and transhipment was first tested in logarithmic terms. Again, the cointegration analysis shows that we cannot reject the hypothesis of a long-

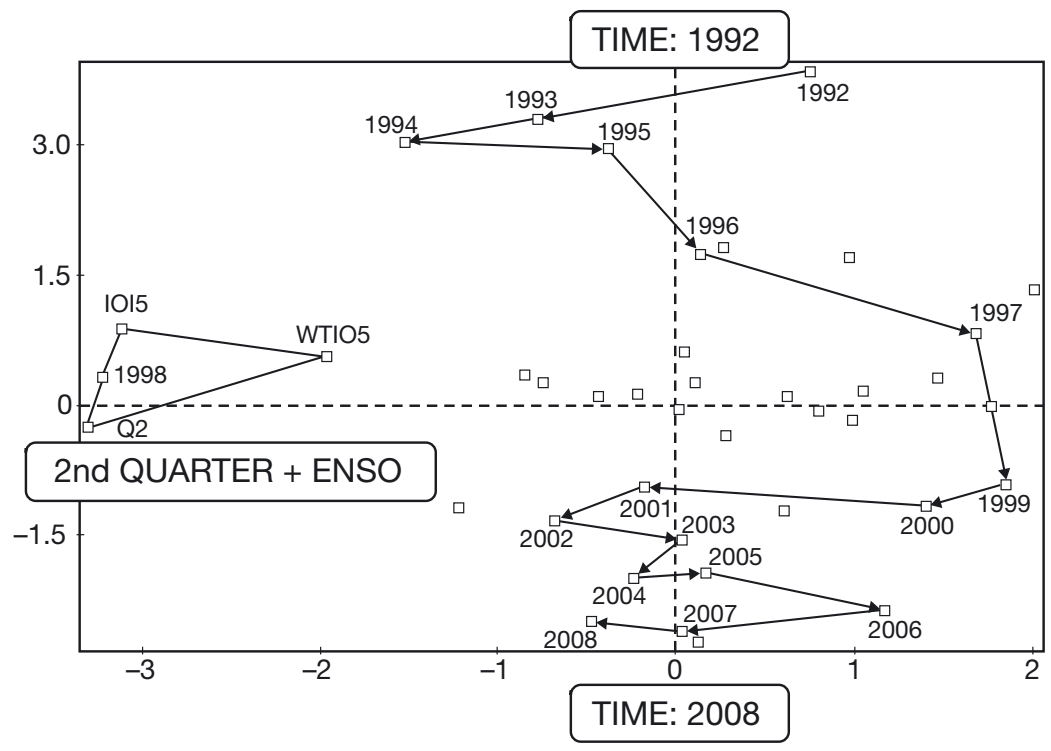

Fig. 7. Projection of nominal purse-seine vessel expenditure variables as a factorial plan, including catch, effort, catch per unit effort and climate indices added as illustrative variables. Q2: second quarter; IOI: Indian Oscillation Index; WTIO: Western Tropical Indian Ocean sea surface temperature index; ENSO: El Niño Southern Oscillation 
Table 1. Results of a trace test for the cointegration analysis (period 1992Q12007Q3)

\begin{tabular}{|lcccc|}
\hline $\begin{array}{l}\text { Hypothesised no. of } \\
\text { cointegration equations }\end{array}$ & Eigenvalue & $\begin{array}{c}\text { Trace } \\
\text { statistic }\end{array}$ & $\begin{array}{c}0.05 \text { critical } \\
\text { value }\end{array}$ & $\mathrm{p}$ \\
\hline 0 & 0.267 & 21.177 & 20.262 & 0.037 \\
At most 1 & 0.042 & 2.564 & 9.165 & 0.665 \\
\hline
\end{tabular}

term equilibrium between the 2 variables (Table 1). The cointegration equation can be written as:

$\ln$ (landings and transhipment) $=$

$0.442 \pm 0.071 \ln ($ gasoil $)+3.327 \pm 1.215$

where \pm values are SD.

Several difficulties arose in the estimation of the VECM. The introduction of dummy variables showed that the estimated coefficients varied according to season. Furthermore, residual variances were not constant and also may have been influenced by season. These difficulties highlighted the need for the analysis to be carried out in a VAR context. The 2 regimes identified constituted the higher level of landings and transhipment occurring during the third and the fourth quarters (Regime 1), and the lower levels of the second quarter and, sometimes, the first quarter (Regime 2). Over 42 observations, the probability $\left(\mathrm{p}^{*}\right)$ of entering Regime 1 is close to $0(<0.05)$ for 16 observations and is close to 1 (>0.95) for 21 observations (Fig. 8). The lowest values of $\mathrm{p}^{*}$ (Regime 2) generally occur when the variarion in landings and transhipment is strongly negative (11 observations out of 15); this occurs mainly during the second quarter when the vessels usually land in other regional ports (11 observations out of 16 are second quarters). While not defined by 3 quarters entering the low regime, 2007 was the only year since 1998 for which there were 2 consecutive quarters in Regime 2.

The best model was obtained with the IOI, the other models exhibiting a lower level of significance (Table 2). With the WTIO, the model did not validate

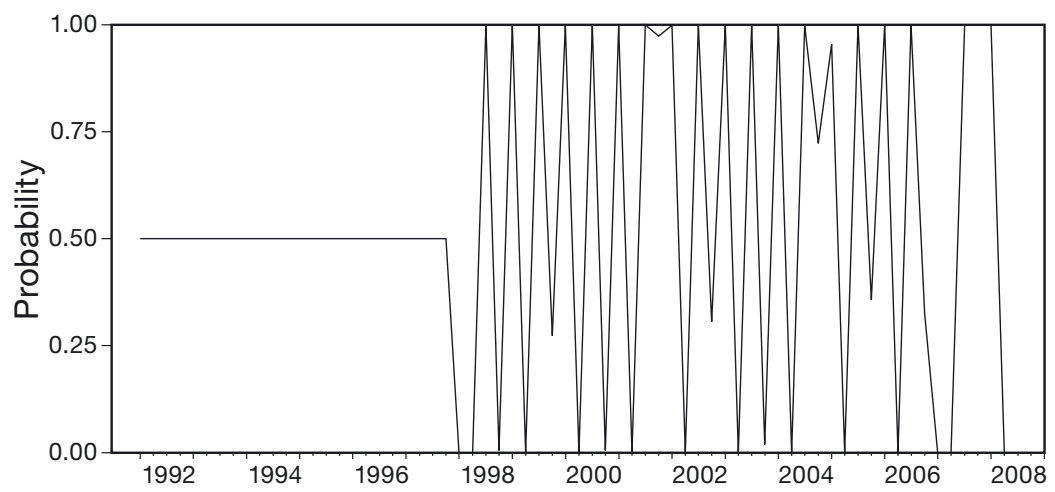

Fig. 8. Results of the Markov-switching Vector Error Correction Model expressed as the probability of entering a regime of high levels of landings (Regime 1) the significance of climate, even at a $90 \%$ level, and the results are not shown. For all climate index models, the seasonal dummy variables exhibit the expected sign, i.e. negative for the second quarter and positive for the first and third quarters. In terms of the IOI index, any strong deviation from the mean significantly decreases the probability of entering the high regime of landings at Port Victoria. Looking at the IOI values, the strongest deviations of the index were negative for the last quarter of 1997 and first quarter of 1998, during the strong ENSO episode. To a lesser extent, the SOI and DMI climate indices also have a negative and significant impact on the regime. Large variations in the climate index can therefore have a depressing influence on landings and transhipment in Seychelles (i.e. entering Regime 2).

\section{DISCUSSION}

The findings of this study provide evidence of a link between climate variability and the tuna economy of Seychelles. While it is recognised that causality was demonstrated using a stepwise rather than an integrated approach, the coincidence of a severe warming events with significant disruptions to the purse-seine tuna fleet and a major loss of revenue for the national economy is compelling evidence for a climate effect. Within the period corresponding to our expenditure dataset (1992-2008), 3 warm anomalies occurred in the WIO, 1 moderate from 2003 to $2005\left(<+2^{\circ} \mathrm{C}\right)$ and 2 strong anomalies $\left(>+2^{\circ} \mathrm{C}\right)$ in $1997-1998$ and 20062007 (Fig. 2a). However, severe deep mixed layer depth (MLD) anomalies, which are known to reduce catchability of tuna, occurred only in late/early 19911992, 1997-1998 and 2006-2007; in spite of moderate warming between 2003 and 2005, the MLD anomaly in that period was not a deepening but a shoaling (Fig. 2b) and catches reached historical highs. In fact, the combination of warmest anomaly, increased MLD and depleted chlorophyll concentration (Fig. 2c) was observed only in 19971998, when the greatest decline in the purse-seine tuna fleet expenditure was experienced. Expenditures also declined in 2007, coinciding with the strong warming anomaly, deep MLD anomaly and slightly depleted chlorophyll. As the magnitude of an anomaly and type of modification to surface habitat appear critical in terms of the economic impact, future research 


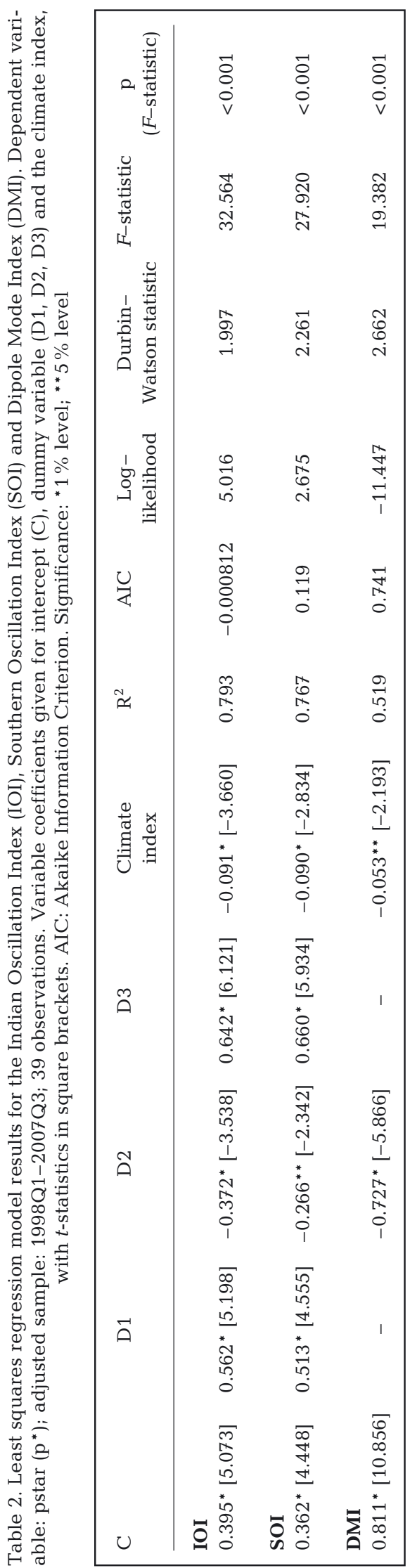

should investigate thresholds to facilitate adaptive management responses.

Although the underlying changes to the fishery differ, the economic impacts of the 1998 warming event can be considered as an extended low season. In the Indian Ocean, the purse-seine tuna fleet demonstrates a high level of spatial mobility by following the seasonal patterns in abundance of tuna and accessibility to surface gears (Miller 2007). Seychelles normally experiences seasonal lows in landings and transhipment during the second quarter of the year, when the fleets target tuna in the northern Mozambique Channel and operate out of other regional ports. In other quarters, landings at Port Victoria are higher and generally stable between years. However, in 1998, the second quarter low season was bracketed by low levels of vessel expenditures in the first and fourth quarters, leading to depressed annual revenue.

Economic impacts resulting from climate oscillations are acute compared to the chronic changes that may characterise climate regime shifts, which are also more difficult to measure or predict (Arnason 2007). After accounting for inflation and seasonal variation, all purse-seine vessel expenditures were sensitive to the 1998 oscillation, the extent of which was dependent on the relative strength of inter-annual trends in landings/ transhipment and service unit costs. For the CHCs, it was estimated that the 1998 episode had a negative impact of $34 \%$ on the purse-seine tuna fleet expenditure in Port Victoria, in line with the cut in landings and transhipment for that year and after taking into consideration the trend and seasonal components. Interestingly, this impact is comparable to ENSO impacts on the Chilean and Peruvian fishmeal fisheries, where the social welfare loss due to ENSO was estimated to be $42 \%$ below a normal year of reference (Sun et al. 2001); the 1998 decrease of spillover in Seychelles (42\%) was identical. Multiplying the fall of revenue in 1998 by our coefficient of induction (2.94) would result in an overall loss of $296 \mathrm{MSR}_{2001}$ for the Seychelles economy.

While the exploratory analysis (PCA) did not group the late 2006 and early 2007 quarters with the low season and 1998 cluster, the MS-VECM identified 2 consecutive quarters at the beginning of 2007 as having a high probability of a low regime in landings and transhipment. This may be explained by the aggregation of a large number of expenditures in the PCA, with some (e.g. increasing bunkering expenditure by 2007) compensating for reduced expenditure(s) related to landings and transhipment, whereas the MS-VECM was based only on CHCs, i.e. stevedoring and plant hire. The declines of purse-seine productivity in late 2006 and early 2007 were coincident with an anomalous deepening of the mixed layer (Fig. 2b). However, this 
anomaly was not distributed uniformly in the WIO, and the fleet partially compensated by concentrating on a small area characterised by a shallow thermocline north of Madagascar (Marsac 2008), rather than relocating to the eastern basin as observed in 1998. Consequently, the vessels continued to use Port Victoria in 2007, but CHCs were low due to the lower level of catch.

One hypothesis that has been proposed to explain this observation identifies a synergistic effect between fishing mortality and environmental anomalies. Stock assessments recently conducted by the Indian Ocean Tuna Commission (IOTC 2008, 2009) concluded that the yellowfin tuna stock was overfished during the 2003-2006 period. During this period, an anomalous shallow mixed layer (ca. $20 \mathrm{~m}$ above normal; Fig. 2b) prevailed over the main fishing grounds, making tuna more accessible and vulnerable to surface gears (Marsac 2008). The other components such as the longline fleet also exhibited high CPUE. The high level of fishing mortality exerted by all gears was considered a consequence of increased catchability due to favourable environmental conditions prevailing in the WIO, among which the enhanced primary productivity between 2002 and 2005 was likely to produce more prey for tunas. Declines in stock biomass, notably of yellowfin tuna, followed a regime of high exploitation rates which lasted 4 yr (2003-2006). By late 2006/early 2007 , the reduced biomass may have acted in concert with the 2006-2007 warming anomaly (coinciding with a deep MLD and slightly depleted chlorophyll, Fig. 2b,c) to depress CPUE and catch (IOTC 2008, 2009).

Climate indices representing dominant climate patterns in the oceans can be good predictors of ecological processes (Bakun 1996, Stenseth et al. 2002, Hallett et al. 2004). The IOI is robust in tracking coupled physical and ecological dynamics in the Indian Ocean (Marsac \& Le Blanc 1998, Ménard et al. 2007, Marsac 2008). Here, we demonstrated its utility in examining economic effects. The climate oscillations described by the IOI and SOI, and to a lesser extent the DMI, influenced the dynamics between landings and transhipment and gasoil consumption (as a proxy for fishing effort), whereby the indices predicted the switching between high and low regimes of landings and transhipment in Port Victoria. Any deviation of the square IOI value from average values decreases the probability of being in a normal (high) landing regime by nearly 10\%, other things being equal. Given that climate oscillations operate on a range of spatial and temporal scales, and that their interrelationships are not fully understood, it is important to examine observations using a range of indices. As an example of this, a moderate impact on expenditures was observed in 1994 in the absence of an ENSO event. However, that year was possibly characterised by a strong IOD event that resulted in warming anomalies in the western basin. While the classification of 1994 as an IOD event is still being debated, it potentially represents an example of an Indian Ocean climate oscillation acting independently of ENSO (Meyers et al. 2007).

To conclude, the potential impacts of climate variability and change on the Seychelles economy are severe. Similar to many SIDS situated in productive tuna fishing zones, Seychelles has come to rely heavily on a 'tuna economy' as world demand for tuna has grown steadily (Campling \& Havice 2007, Campling et al. 2007). The multiplier approach demonstrated the importance of this industry for domestic wealth. In terms of employment, recent analyses of direct, indirect and induced employment indicate that 8400 persons are dependent on the tuna industry and related activities (L. Campling pers. comm.), constituting approximately $10 \%$ of the Seychelles' population. Stakeholders of the tuna industry, including the cannery, generally perceive climate variability to be a relatively unimportant threat compared to changes in trade regimes, piracy, regional competition and overfishing (Robinson et al. 2009), and the industry has demonstrated a degree of resilience to recent warm events. However, this situation may change given the predicted interaction of background warming on the occurrence of the central Pacific El Niño (Yeh et al. 2009) and changes in the distribution and magnitude of fisheries resources caused by climate change (Loukos et al. 2003, Sun et al. 2006, Cheung et al. 2009). The incorporation of climate variability in population and bio-economic fisheries models will be important for fisheries assessment and management (e.g. Sun et al. 2006), as well as for building adaptive capacity.

Building adaptive capacity is critical to alleviating the socio-economic impacts resulting from climate variability and change (Allison et al. 2009). While this study was largely based on economic analyses, the potential social impacts are pervasive with reductions in government revenues from fisheries undermining social policy interventions (e.g. health, education and housing). The coral reef fisheries, important for food security as well as employment, are also threatened by climate change (Graham et al. 2007), and tourism, the second pillar of the economy, is threatened by coastal erosion and degraded reef sites (Payet 2005). While Seychelles has a relatively high adaptive capacity to cope with climate change, compared to other countries in the region (McClanahan et al. 2008), the reliance on the marine environment to support the 2 main pillars of the economy warrants a greater emphasis on strengthening adaptive capacity through mainstreaming of climate change in national policy and management interventions. 
Acknowledgements. This study was funded by a GEF/UNDP project 'Enabling Activities for the Preparation of Seychelles' Second National Communication to the UNFCCC' and supported by SFA. We thank the UNDP Project Coordination Unit and the Seychelles National Climate Change Committee for their support and encouragement during the study. L. Campling and J. Beddington provided important advice. We are also grateful for the valuable contribution of data and information by numerous stakeholders and institutions in Seychelles, and to SFA for maintaining such excellent data collection systems and databases since the development of the tuna industry.

\section{LITERATURE CITED}

Allison EH, Perry AL, Badjeck MC, Adger WN and others (2009) Vulnerability of national economies to the impacts of climate change. Fish Fish 10:173-196

Arnason R (2007) Climate change and fisheries: assessing the economic impact in Iceland and Greenland. Nat Resour Model 20:163-197

Bakun A (1996) Patterns in the ocean: ocean processes and marine population dynamics. University of California Sea Grant, San Diego, CA

Campling L, Havice E (2007) Industrial development in an island economy: US trade policy and canned tuna production in American Samoa. Isl Stud J 2:209-228

Campling L, Havice E, Ram-Bidesi V (2007) Pacific island countries, the global tuna industry and the international trade regime: a guidebook. Forum Fisheries Agency, Honiara

Cayré P, Marsac F (1993) Modelling the yellowfin tuna (Thunnus albacares) vertical distribution using sonic tagging results and local environmental parameters. Aquat Living Resour 6:1-14

Cheung WWL, Lam VWY, Sarmiento JL, Kearney K, Watson R, Zeller D, Pauly D (2010) Large-scale redistribution of maximum fisheries catch potential in the global ocean under climate change. Glob Change Biol 16:24-35

> Dickey DA, Fuller W (1981) Likelihood ratio statistics for autoregressive time series with a unit root. Econometrica 49:1057-1072

Evans RH, Maclain DR, Bauer RA (1981) Atlantic skipjack tuna: influences of the environment on their vulnerability to surface gear. Collect Vol Sci Pap ICCAT 9:264-274

Glantz MH (1996) Currents of change: El Niño's impact on climate and society. Cambridge University Press, Cambridge

Graham NAJ, Wilson SK, Jennings S, Polunin NVC, Robinson J, Bijoux J, Daw T (2007) Lag effects in the impacts of mass coral bleaching on coral reef fish, fisheries and ecosystems. Conserv Biol 21:1291-1300

Hall SG, Milne A (1994) The relevance of p-star analysis to UK monetary policy. Econ J 104:597-604

Hallett TB, Coulson T, Pilkington JG, Clutton-Brock TH, Pemberton JM, Grenfell BT (2004) Why large-scale climate indices seem to predict ecological processes better than local weather. Nature 430:71-75

IOTC (Indian Ocean Tuna Commission) (2008) Report of the eleventh session of the Scientific Committee. Victoria, Seychelles, 1-5 December 2008. IOTC-2008-SC-R[E]

IOTC (2009) Report of the twelfth session of the Scientific Committee. Victoria, Seychelles, 30 November-4 December 2009. IOTC-2009-SC-R[E]

Johansen S (1988) Statistical analysis of cointegration vectors. J Econ Dyn Control 12:231-254

Johansen S (1995) Likelihood-based inference in cointegrated vector autoregressive models. Oxford University Press, Oxford
Johansen S, Juselius K (1990) Maximum likelihood estimation and inference on cointegration - with applications to the demand for money. Oxf Bull Econ Stat 52:169-210

Johansen S, Juselius K (1992) Testing structural hypotheses in a multivariate cointegration analysis of the PPP and the UIP for UK. J Econom 53:211-244

> Johansen S, Juselius K (1994) Identification of the long-run and the short-run structure: an application to the ISLM model. J Econom 63:7-36

Kwiatkowski D, Phillips PCB, Schmidt P, Shin Y (1992) Testing the null hypothesis of stationarity against the alternative of a unit root. J Econom 54:159-178

> Lehodey P, Bertignac M, Hampton J, Lewis A, Picaut J (1997) El Niño Southern Oscillation and tuna in the western Pacific. Nature 389:715-718

> Lehodey $\mathrm{P}$, Alheit J, Barange M, Baumgartner T and others (2006) Climate variability, fish and fisheries. J Clim 19: $5009-5030$

Leontief W (1970) Environmental repercussions and the economic structure: an input-output approach. Rev Econ Stat $52: 262-271$

Loukos H, Monfray P, Bopp L, Lehodey P (2003) Potential changes in skipjack tuna (Katsuwonus pelamis) habitat from a global warming scenario: modelling approach and preliminary results. Fish Oceanogr 12:474-482

Lütkepohl H (2005) New introduction to multiple time series analysis. Springer-Verlag, Berlin

Marsac F (1991) Hydroclimat et ressources thonières tropicales. In: Le Gall JY, De Reviers X, Roger C (eds) Actes de la Conférence Thonière Régionale. Commission de l'Ocean Indien, ORSTOM, Paris, p 79-90

Marsac F (1998) Environnement océanique et pêche thonière: l'environnement océanique et son impact sur la pêche thonière hauturière; des relations individuelles et locales aux processus générés à l'échelle de l'océan. In: Cayré $P$, Le Gall JY (eds) Le thon: enjeux et stratégies pour l'océan Indien. Conférence Internationale Thonière, Ile Maurice, 27-29 Nov 1996, ORSTOM, Paris, p 139-176

Marsac F (2008) Outlook of ocean climate variability in the west tropical Indian Ocean, 1997-2008. IOTC-2008WPTT-27, IOTC Proc No 11

Marsac F, Le Blanc JL (1998) Interannual and ENSO-associated variability of the coupled ocean-atmosphere system with possible impacts on the yellowfin tuna fisheries of the Indian and Atlantic oceans. In: Beckett JS (ed) ICCAT tuna symposium. Collect Vol Sci Pap ICCAT 50:345-377

Marsac F, Le Blanc JL (1999) Oceanographic changes during the 1997-1998 El Niño in the Indian Ocean and their impact on fisheries. IOTC Proc No 2, p 147-157

McClanahan TR, Cinner JE, Maina J, Graham NAJ and others (2008) Conservation action in a changing climate. Conserv Lett 1:53-59

Ménard F, Marsac F, Bellier E, Cazelles B (2007) Climatic oscillations and tuna catch rates in the Indian Ocean: a wavelet approach to time series analysis. Fish Oceanogr 16:95-104

Meyers G, McIntosh P, Pigot L, Pook M (2007) The years of El Niño, La Niña, and interactions with the Tropical Indian Ocean. J Clim 20:2872-2880

Miller KA (2007) Climate variability and tropical tuna: management challenges for highly migratory stocks. Mar Policy 31: $56-70$

Murtugudde R, McCreary JP Jr, Busalacchi AJ (2000) Oceanic processes associated with anomalous events in the Indian Ocean with relevance to 1997-1998. J Geophys Res 105:3295-3306

Nicholson SE (1997) An analysis of the ENSO signal in the 
tropical Atlantic and Western Indian Oceans. Int J Climatol $17: 345-375$

Osterwald-Lenum M (1992) A note with quantiles of the asymptotic distribution of the maximum likelihood cointegration rank test statistics. Oxf Bull Econ Stat 54:461-472

Payet RA (2005) Climate policy implications of the recent ENSO events in a small island context. In: Pak SL (ed) Climate and Africa. Cambridge University Press, Cambridge, p 228-237

Reynolds RW, Rayner NA, Smith TM, Stokes DC, Wang W (2002) An improved in situ and satellite SST analysis for climate. J Clim 15:1609-1625

Robinson J, Guillotreau P, Jiménez-Toribio R, Lantz F and others (2009) Socio-economic impacts of climate variability on Seychelles tuna industry. UNDP/GEF/Government of Seychelles, Victoria

Saji NH, Goswani BN, Vinayachandran PN, Yamagata T (1999) A dipole mode in the tropical Indian Ocean. Nature 401:360-363

Stenseth NC, Mysterud A, Ottersen G, Hurrell JW, Chan KS, Lima M (2002) Ecological effects of climate fluctuations. Science 297:1292-1296

Stopford M (1997) Maritime economics. Routledge, London

Sun CH, Chiang FS, Liu TS, Chang CC (2001) A welfare analysis of El Niño forecasts in the international trade of fish meal-an application of Stochastic Spatial Equilibrium Model. Selected Paper of the Annual Meetings of the American Agricultural Economics Association, Tampa, FL, 5-8 August 2001

Sun CH, Chiang FS, Tsoa E, Chen MH (2006) The effects of El
Niño on the mackerel purse-seine fishery harvests in Taiwan: an analysis integrating the barometric readings and sea surface temperature. Ecol Econ 56:268-279

Tiffin R, Dawson PJ (2000) Structural breaks, cointegration and the farm-retail price spread for lamb. Appl Econ 32: $1281-1286$

- Timmermann A, Oberhuber J, Bacher A, Esch M, Latif M, Roeckner E (1999) Increased El Niño frequency in a climate model forced by future greenhouse warming. Nature 398:694-697

Tourre YM, White WB (1995) ENSO signals in global upperocean temperature. J Phys Oceanogr 25:1317-1332

Weber AP (1993) Abandoned seas: reversing the decline of the oceans. World Watch Paper 116, World Watch Institute, Washington, DC

> Webster PJ, Moore AM, Loschnigg JP, Leben RR (1999) Coupled ocean atmosphere dynamics in the Indian Ocean during 1997-98. Nature 401:356-360

Wright PB (1975) An index of the Southern Oscillation. CRU RP4 Climate Research Unit, School of Environmental Sciences, University of East Anglia, Norwich

Yeh SW, Kug JS, Dewitte B, Kwon MH, Kirtman BP, Jin FF (2009) El Niño in a changing climate. Nature 461: 511-514

Yuen HS (1970) Behaviour of skipjack tuna (Katsuwonus pelamis), as determined by tracking with ultrasonic devices. J Fish Res Board Can 27:2071-2079

Zeller D, Booth S, Pauly D (2006) Fisheries contributions to the gross domestic product: under-estimating small-scale fisheries in the Pacific. Mar Resour Econ 21:355-374

Appendix. List and description of the fields (variables) in the study database on purse-seine vessel expenditure and fishery data

\begin{tabular}{|c|c|c|c|}
\hline Field & Description & Field & Description \\
\hline Portdues & Port charges and costs related to entering & Staffovert & Payment of overtime for agency staff \\
\hline & and leaving ports such as pilot fees & Electserv & $\begin{array}{l}\text { Costs of electronic services and refrigera- } \\
\text { tion }\end{array}$ \\
\hline Agcylee & Shin & Miscelfuel & Cost of miccellanoous fuel other than casoil \\
\hline Telephone & Expenses paid to phone & IVISCEIIUEI & and fuel oil \\
\hline & telephone, telex and fax services & \multirow[t]{2}{*}{ Slipengine } & \multirow{2}{*}{$\begin{array}{l}\text { Cost of repairs and maintenance for marine } \\
\text { and engineering works }\end{array}$} \\
\hline Travel & Cost of car hires and travel agents & & \\
\hline Stevedorin & Labour cost for stevedores & \multirow{2}{*}{ TotalNoOil } & Costs of accommodation for crew \\
\hline Agtrans & $\begin{array}{l}\text { Expenses paid to shipping agencies for } \\
\text { transport such as for crew change }\end{array}$ & & $\begin{array}{l}\text { Total expenditures excluding gasoil and } \\
\text { fuel oil }\end{array}$ \\
\hline Advtomast & Advance to master & Gasoil_Rs & Cost of gasoil \\
\hline Water & Payments made for water consumption & Fuel_Rs & Cost of fuel oil \\
\hline Planthire & Cost of plant hire, sundry bill & GrandTotal & Total expenses (including gasoil and fuel oil) \\
\hline Crewsalary & Payment of salaries for Seychellois crew & $\begin{array}{l}\text { TotalExpend } \\
\text { ('000) }\end{array}$ & $\begin{array}{l}\text { Total expenses (including gasoil and fuel } \\
\text { oil) in r1000 }\end{array}$ \\
\hline Marinebrok & Marine broker fees & Effort & Purse seine fishing effort (fishing days) \\
\hline Fishpurch & Purchases of fish & TotalCatch & Purse seine total catch (mt) \\
\hline $\begin{array}{l}\text { Garbage } \\
\text { Casullabour }\end{array}$ & $\begin{array}{l}\text { Cost for removal of garbage and waste oil } \\
\text { Payment for casual labour }\end{array}$ & Landing & $\begin{array}{l}\text { Purse seine total landed/transhipped catch } \\
\text { (mt) }\end{array}$ \\
\hline Bondcertif & Bond forms (tax) & \%Land/Catch & $\%$ of catch landed/transhipped in Port \\
\hline Hospmedic & $\begin{array}{l}\text { Medical expenses such as hospital bill, } \\
\text { pharmacies, dental services }\end{array}$ & CPUE & Catch per unit effort ( $m t$ fishing $\mathrm{d}^{-1}$ ) \\
\hline Custombill & $\begin{array}{l}\text { Government taxes such as clearing, import } \\
\text { cargo charge, cartage \& delivery }\end{array}$ & Others & $\begin{array}{l}\text { Contains aggregated data for when } \\
\text { variables are not specified or are grouped }\end{array}$ \\
\hline
\end{tabular}

